\title{
Results from the first national UK inter-laboratory calibration for very short-lived halocarbons
}

\author{
C. E. Jones ${ }^{1}{ }^{*}$, S. J. Andrews ${ }^{1}$, L. J. Carpenter ${ }^{1}$, C. Hogan ${ }^{2}$, F. E. Hopkins ${ }^{3}$, J. C. Laube $^{2}$, A. D. Robinson ${ }^{4}$, \\ T. G. Spain ${ }^{5}$, S. D. Archer ${ }^{3}$, N. R. P. Harris ${ }^{4}$, P. D. Nightingale ${ }^{3}$, S. J. O'Doherty ${ }^{6}$, D. E. Oram ${ }^{2}$, J. A. Pyle ${ }^{4}$, \\ J. H. Butler ${ }^{7}$, and B. D. Hall ${ }^{7}$ \\ ${ }^{1}$ Department of Chemistry, University of York, Heslington, York, YO10 5DD, UK \\ ${ }^{2}$ School of Environmental Sciences, University of East Anglia, Norwich, NR4 7TJ, UK \\ ${ }^{3}$ Plymouth Marine Laboratory, The Hoe, Plymouth, Devon, PL1 3DH, UK \\ ${ }^{4}$ Centre for Atmospheric Science, Department of Chemistry, University of Cambridge, Cambridge, CB2 1EW, UK \\ ${ }^{5}$ School of Physics, National University of Ireland, Galway, Ireland \\ ${ }^{6}$ Atmospheric Chemistry Research Group, University of Bristol, Bristol, BS8 1TS, UK \\ ${ }^{7}$ Global Monitoring Division, NOAA Earth System Research Laboratory, Boulder, Colorado, USA \\ * now at: Department of Applied Chemistry, Faculty of Urban Environmental Sciences, Tokyo Metropolitan University, \\ Minami-osawa 1-1, Hachioji-shi, Tokyo, 192-0397, Japan
}

Received: 19 December 2010 - Published in Atmos. Meas. Tech. Discuss.: 28 January 2011

Revised: 22 April 2011 - Accepted: 26 April 2011 - Published: 12 May 2011

\begin{abstract}
Very short-lived halocarbons (VSLH) such as $\mathrm{CH}_{3} \mathrm{I}, \mathrm{CH}_{2} \mathrm{Br}_{2}$ and $\mathrm{CHBr}_{3}$ provide an important source of reactive halogens to the atmosphere, however high spatial and seasonal variability in their ambient mixing ratios and sea-air fluxes gives rise to considerable uncertainty in global scale emission estimates. One solution to improve global flux estimates is to combine the multitude of individually published datasets to produce a database of collated global halocarbon observations. Some progress towards this has already been achieved through the HalOcAt (Halocarbons in the Ocean and Atmosphere) database initiative, but the absence of a common calibration scale for very short-lived halocarbons makes it difficult to distinguish true environmental variations from artefacts arising from differences between calibration methodologies. As such, the lack of intercalibrations for both air and seawater measurements of very short-lived halocarbons has been identified as a major limitation to current estimations of the global scale impact of these reactive trace gases. Here we present the key findings from the first national UK inter-laboratory comparison for calibrations of the halocarbons $\mathrm{CH}_{3} \mathrm{I}, \mathrm{CH}_{2} \mathrm{Br}_{2}$ and $\mathrm{CHBr}_{3}$. The aim of this inter-calibration was to provide transparency
\end{abstract}

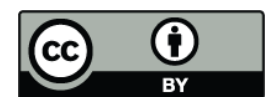

Correspondence to: L. J. Carpenter (lucy.carpenter@york.ac.uk) between halocarbon calibrations from major UK research institutions, an important step towards enabling all measurements from these institutions to be treated as one coherent integrated dataset for global source term parameterisations.

\section{Introduction}

Very short-lived halocarbons or VSLH (defined as those with atmospheric lifetimes of less than six months, Law and Sturges, 2007) of predominantly biogenic marine origin are thought to supply a substantial fraction of reactive halogens to the marine boundary layer (MBL) (Carpenter et al., 2003; Jones et al., 2010), free troposphere (von Glasow et al., 2004; Yang et al., 2005) and lower stratosphere (Garcia and Solomon, 1994; Sturges et al., 2000; Liang et al., 2010 and references therein), potentially influencing both stratospheric and tropospheric photochemistry and climate.

Photo-destruction of volatile organic iodine- and brominecontaining trace gases to release $\mathrm{I}$ and $\mathrm{Br}$ atoms within the troposphere can initiate catalytic ozone depletion and impact upon $\mathrm{NO} / \mathrm{NO}_{2}$ and $\mathrm{OH} / \mathrm{HO}_{2}$ chemistry, which in turn affects the atmospheric lifetimes of other climatically important trace gases (Vogt et al., 1999; Bloss et al., 2005; Read et al., 2008; Whalley et al., 2010; Mahajan et al., 2010).

Published by Copernicus Publications on behalf of the European Geosciences Union. 
While the majority of organic iodine compounds (or iodocarbons) are broken down within the troposphere, the relatively longer lived bromocarbons (e.g. $\mathrm{CH}_{2} \mathrm{Br}_{2}$ and $\mathrm{CHBr}_{3}$, with respective lifetimes of 3-4 months and $\sim 3$ 5 weeks; Quack et al., 2007) are thought to contribute $\sim 15-40 \%$ of stratospheric bromine (Montzka and Reimann, 2011). Bromine-catalysed stratospheric ozone depletion is on average $\sim 60$ times more efficient than chlorine-initiated ozone destruction (Law and Sturges, 2007), yet to date sources of stratospheric bromine have been less well quantified.

The number of published VSLH datasets has increased substantially in recent years (including Quack and Wallace, 2003 and references therein; Chuck et al., 2005; Archer et al., 2007; Carpenter et al., 2007; Quack et al., 2007; Laube et al., 2008; Varner et al., 2008; O'Brien et al., 2009; Carpenter et al., 2009; Jones et al., 2010; Kurihara et al., 2010), and includes atmospheric and oceanic measurements, and sea-air flux estimates. However, there remains considerable uncertainty associated with global source term estimates for these gases (e.g. annual global $\mathrm{CHBr}_{3}$ source estimated as $\sim 10 \mathrm{Gmol} \mathrm{Br} \mathrm{yr}^{-1}$, but including the quantifiable uncertainties gives the range $3-22 \mathrm{Gmol} \mathrm{Br} \mathrm{yr}^{-1}$; Quack and Wallace, 2003). This high level of variability is the result of several factors, including the spatial and seasonal variability in VSLH biological production and sea-air transport rates, their short tropospheric lifetimes, the sparse availability of data which may be considered representative of regional sources (i.e. made in the free troposphere or over the open ocean), and the lack of a common calibration scale for these gases. Improved quantification of the global emission budget for these short-lived halocarbons requires an integrated approach, combining as many datasets as possible, in order to maximise the temporal and spatial resolution.

The Halocarbons in the Ocean and Atmosphere (HalOcAt) database project is a current SOLAS/COST initiative hosted by IFM-GEOMAR, which aims to collate atmospheric and oceanic VSLH observations from across the international research community (https://halocat.ifm-geomar.de). However, the lack of formal comparisons between the various calibration techniques used by different research groups to quantify halocarbons has been identified as one of the major limitations to effectively utilising this type of integrated dataset to improve global emissions estimates. Indeed it is currently difficult to discern with any certainty whether observational differences are naturally occurring, or are simply artefacts of differences in measurement and calibration techniques. Given the potential benefits of compiling a coherent global database for measurements of very short-lived halocarbons within the atmosphere and ocean, there is a general consensus within the community for the need to link individual datasets to a common calibration scale (Butler et al., 2010). Such calibration scales are already in place for longer lived atmospheric trace gases, such as $\mathrm{CH}_{4}$ and $\mathrm{CO}_{2}$, however the comparative instability of shorter-lived gases in metal canisters for prolonged periods (Finlayson-Pitts and Pitts, 2000), coupled with the very limited number of stability studies, makes large scale inter-calibrations for these gases less straightforward.

A meeting of international scientists from the halocarbon measurement community in London in February 2008 highlighted the need for more formal inter-laboratory calibrations for these short-lived gases (Butler et al., 2010). Whilst the ultimate goal would be to undertake an international inter-calibration, encompassing all research laboratories that routinely monitor very short-lived halocarbons, funding and logistical constraints mean that to date this has not been achieved. However, the UK halocarbon measurement community has taken an initial step towards this goal, and we report here the key findings from the first formal UK inter-laboratory comparison of calibrations for very shortlived halocarbons.

\section{Methods}

Research groups from the following institutions participated in the UK inter-laboratory comparison of calibrations for very short-lived halocarbons, as part of the UK National Environment Research Council (NERC) Quantifying and Understanding the Earth System (QUEST) initiative, between June and November 2010:

- The University of Bristol (UoB, Mace Head Atmospheric Station, Ireland)

- The University of Cambridge (UoC)

- The University of East Anglia (UEA)

- Plymouth Marine Laboratory (PML)

- The University of York (UoY)

\subsection{The inter-calibration gas standard}

Each laboratory's existing calibration technique was compared to the NOAA (National Oceanic and Atmospheric Administration, US) calibration scales, through the exchange of a compressed gas standard, SX-3570. The multi-component gas standard (in an electropolished stainless steel canister, Essex Cryogenics, St. Louis, MO, US) containing both VSLH and longer-lived halocarbons in modified continental background air (from Niwot Ridge, Colorado) was prepared and analysed by the NOAA Earth System Research Laboratory (ESRL) Global Monitoring Division in Boulder, Colorado. For those halocarbons with very low background air concentrations, the standard was spiked with additional volumes of high concentration halocarbons, in order to generate mixing ratios $\sim 2-5 \mathrm{ppt}$ above ambient levels. NOAA-ESRL determined VSLH mixing ratios in SX3570 by gas chromatography with mass-selective detection 
Table 1. Summary of $\mathrm{CH}_{3} \mathrm{I}, \mathrm{CH}_{2} \mathrm{Br}_{2}$ and $\mathrm{CHBr}_{3}$ mixing ratios as assigned by NOAA and determined by the individual UK research laboratories, together with the $2 \sigma$ precision in the inter-calibration analyses and the estimated $2 \sigma$ (95.4\% confidence interval) overall uncertainty in the reported mixing ratio (incorporating both systematic uncertainties and precision), $U$. The number of data points used to derive the reported mixing ratio is given in brackets.

\begin{tabular}{|c|c|c|c|c|c|c|c|c|}
\hline Institution & $\begin{array}{l}\text { Date of } \\
\text { analysis }\end{array}$ & Calibration scale & $\begin{array}{c}\mathrm{CH}_{3} \mathrm{I}( \pm 2 \sigma) \\
(\mathrm{ppt})\end{array}$ & $\begin{array}{c}U \\
(2 \sigma) \\
(\mathrm{ppt})\end{array}$ & $\begin{array}{c}\mathrm{CH}_{2} \mathrm{Br}_{2}( \pm 2 \sigma) \\
\text { (ppt) }\end{array}$ & $\begin{array}{c}U \\
(2 \sigma) \\
(\mathrm{ppt})\end{array}$ & $\begin{array}{c}\mathrm{CHBr}_{3}( \pm 2 \sigma) \\
(\mathrm{ppt})\end{array}$ & $\begin{array}{c}U \\
(2 \sigma) \\
(\mathrm{ppt})\end{array}$ \\
\hline NOAA & 9 Sep 2009 & NOAA & $3.8 \pm 0.2$ & 0.79 & $2.6 \pm 0.2$ & 0.56 & $5.4 \pm 0.2$ & 0.58 \\
\hline University of Cambridge & 12 Oct 2010 & NOAA & $4.76 \pm 1.82(8)$ & 2.05 & $* 3.01 \pm 0.42(8)$ & 0.80 & $6.26 \pm 0.64(8)$ & 0.90 \\
\hline University of East Anglia & 9 Jun 2010 & NOAA & $3.91 \pm 0.04$ (4) & 0.94 & $2.62 \pm 0.06(4)$ & 0.66 & $6.20 \pm 0.88$ & 1.55 \\
\hline University of York & 25 Oct 2010 & York (permeation oven) & $2.97 \pm 0.08$ (3) & 0.34 & $3.18 \pm 0.10(3)$ & 0.42 & $5.30 \pm 0.20(3)$ & 0.63 \\
\hline Mean & & & 3.35 & & 2.42 & & 6.51 & \\
\hline Median & & & 3.33 & & 2.66 & & 6.20 & \\
\hline$\%$ standard deviation & & & $33 \%$ & & $41 \%$ & & $25 \%$ & \\
\hline
\end{tabular}

*Note that the University of Cambridge GC-ECD was not able to distinguish between $\mathrm{CH}_{2} \mathrm{Br}_{2}$ and $\mathrm{CHBrCl}_{2}$, which co-elute on their system. However, subtraction of the NOAAassigned $\mathrm{CHBrCl}_{2}$ mixing ratio from the combined $\mathrm{CHBrCl}_{2}$ and $\mathrm{CH}_{2} \mathrm{Br}_{2}$ signal (and based on an instrument response for $\mathrm{CHBrCl}_{2}$ of 0.84 times the $\mathrm{CH}_{2} \mathrm{Br}_{2}$ response) gives the value indicated.

(GC/MS) (Montzka et al., 1993, 1996). Samples were analyzed relative to gravimetrically-prepared standards (cylinders similar to SX-3570, Butler et al., 2007). The mixing ratios assigned by NOAA for the VSLH targeted for the comparison $\left(\mathrm{CH}_{3} \mathrm{I}, \mathrm{CH}_{2} \mathrm{Br}_{2}\right.$ and $\left.\mathrm{CHBr}_{3}\right)$ are given in Table 1. $\mathrm{CHBr}_{3}$ was calibrated based upon the NOAA-2003 scale, whilst $\mathrm{CH}_{3} \mathrm{I}$ and $\mathrm{CH}_{2} \mathrm{Br}_{2}$ were calibrated according to the NOAA-2004 scale. The SX-3570 gas standard also contains other short-lived polyhalogenated methanes, including $\mathrm{CH}_{2} \mathrm{I}_{2}, \mathrm{CH}_{2} \mathrm{ICl}$ and $\mathrm{CHBrCl}_{2}$, however the stability of these gases in canisters has not been well characterised, and hence only provisional mixing ratios were assigned for these compounds. The initial quantification of VSLH in SX-3570 was carried out by NOAA in September 2009. Analyses by UK research groups took place between June and November 2010. Stability studies of NOAA halocarbon gas standards prepared and contained under the same conditions as SX-3570 indicate that $\mathrm{CH}_{3} \mathrm{I}, \mathrm{CH}_{2} \mathrm{Br}_{2}$ and $\mathrm{CHBr}_{3}$ mixing ratios are generally relatively stable over this timescale, with drift rates of $<2-5 \% \mathrm{yr}^{-1}$ (Butler et al., 2007, Supplement). In addition, NOAA-ESRL have carried out longer term stability tests on six such canisters containing continental background mixing ratios of $\mathrm{CHBr}_{3}, \mathrm{CH}_{2} \mathrm{~B}_{r 2}$, and $\mathrm{CH}_{3} \mathrm{I}(<1 \mathrm{ppt})$ over a 3 year period (2004-2007; during the International HALocarbons in Air Comparison Experiment (IHALACE), manuscript in preparation), and all three gases showed no significant changes over this time.

\subsection{Calibration and analysis methods}

Details of the analytical systems and calibration techniques used by each group during the inter-comparison are outlined below. For all analyses a high-purity stainless steel HFS4A pressure regulator (Swagelok) was used to supply the SX3570 gas standard at a constant pressure (30 psig).

\subsubsection{University of Bristol (Mace Head)}

All comparisons were carried out using the Medusa-MS (custom pre-concentration device coupled to an Agilent $6890 \mathrm{GC}$ and Agilent 5973 MSD). 2 L samples were pre-concentrated on a trap held at $-150^{\circ} \mathrm{C}$ to $-170^{\circ} \mathrm{C}$ and were subsequently analysed using a single main capillary chromatography column $($ CP-PoraBOND Q, $0.32 \mathrm{~mm}$ ID $\times 25 \mathrm{~m}, 5 \mu \mathrm{m}$, Varian Chrompack) with temperature and pressure ramping (Miller et al., 2008). Prior to trapping the system was flushed with sample gas at $100 \mathrm{ml} \mathrm{min}^{-1}$ for $70 \mathrm{~s}$.

The MS was operated in EI-SIM (Electron ImpactSelected Ion Monitoring) mode using a single target ion and one or two qualifier ions as a check for the correct ion ratios. The starting column temperature was $40^{\circ} \mathrm{C}$, this was ramped on injection of the sample to $200^{\circ} \mathrm{C}$ at $28^{\circ} \mathrm{C} \mathrm{min}^{-1}$. $\mathrm{CH}_{3} \mathrm{I}$ was quantified using the $\mathrm{CH}_{3} \mathrm{I}^{+}$ion $(\mathrm{m} / \mathrm{z}, 142)$ with $\mathrm{I}^{+}(\mathrm{m} / \mathrm{z}, 127)$ as a qualifier, whilst $\mathrm{CH}_{2} \mathrm{Br}_{2}$ was quantified via $\mathrm{CH}_{2} \mathrm{Br}_{2}^{+}(\mathrm{m} / \mathrm{z}, 174)$ with $\mathrm{CH}_{2} \mathrm{Br}^{+}(\mathrm{m} / \mathrm{z}, 93)$ and $\mathrm{CH}_{2} \mathrm{Br}^{+}(\mathrm{m} / z, 95)$ as qualifier ions, and finally $\mathrm{CHBr}_{3}$ on $\mathrm{CH}\left({ }^{79} \mathrm{Br}\right)\left({ }^{81} \mathrm{Br}\right)^{+}\left(\mathrm{m} / z\right.$ 173) with $\mathrm{CH}\left({ }^{79} \mathrm{Br}\right)\left({ }^{79} \mathrm{Br}\right){ }^{+}(\mathrm{m} / z$ 171) as a qualifier ion. 
The NOAA standard SX-3570 was compared against a tertiary standard (J-128), filled during relatively clean-air conditions at Trinidad Head using modified diving compressors (SA-6, RIX Industries), and measured against secondary standards at Scripps Institution of Oceanography (SIO) to check for drift before and after usage at Mace Head. In the case of $\mathrm{CH}_{2} \mathrm{Br}_{2}$ and $\mathrm{CHBr}_{3}$, preliminary calibration values were assigned by comparison to a commercial gas standard prepared by Linde Gas Ltd. In the case of $\mathrm{CH}_{3} \mathrm{I}$, a preliminary calibration was assigned via comparison to a gas standard provided by Y. Yokouchi (National Institute for Environmental Studies, NIES, Japan). The precision of the SX3570 to J-128 measurement was $\sim 2 \%$ for $\mathrm{CH}_{3} \mathrm{I}, \sim 0.7 \%$ for $\mathrm{CH}_{2} \mathrm{Br}_{2}$ and $\sim 1.2 \%$ for $\mathrm{CHBr}_{3}(n=10)$. No blank corrections were applied to the data. The Medusa-MS has demonstrated linearity for concentrations of up to 12 times higher than typical background ambient mixing ratios for $\mathrm{CHBr}_{3}$ and 8 times ambient $\mathrm{CH}_{2} \mathrm{Br}_{2}$ mixing ratios.

\subsubsection{University of Cambridge}

At Cambridge, the calibration comparison was carried out using a GC-ECD (gas chromatograph with electron capture detection) system similar to that described by Gostlow et al. (2010) but with improved sample pre-concentration (thermally regulated) and separation (longer column). The inter-calibration standard SX-3570 was compared to the Cambridge working standard (NOAA cylinder no. SX-3568; $\mathrm{CHBr}_{3}$ calibrated according to the NOAA 2003 scale and $\mathrm{CH}_{3} \mathrm{I}$ and $\mathrm{CH}_{2} \mathrm{Br}_{2}$ calibrated based upon the 2004 scale) using a sequence of samples analysed over a $24 \mathrm{~h}$ period. The SX-3570 standard was treated as an unknown sample and the Cambridge working standard was used to achieve calibration. The sequence generated 8 sample chromatograms from analysis of SX-3570 and 9 calibration chromatograms of the Cambridge working standard (with sample volumes from 3-50 ml), to produce response curves which were used to calibrate the samples. Blank chromatograms were run following each sample or calibration chromatogram by passing helium carrier gas through the adsorbent bed (these served as a check on desorption efficiency and system impurities, and were sufficiently clean that blank corrections were not necessary).

Each sample or calibration chromatogram was generated as follows: the system was flushed with $\sim 11$ gas prior to sampling, after which a flow $\left(\sim 10 \mathrm{ml} \mathrm{min}^{-1}\right)$ of either sample or calibration air was passed through a dual bed adsorbent (1 mg each of Carboxen 1016/1001) held in an Ultimetal tube $\left(1 / 32^{\prime \prime}\right.$ od $\times 0.53 \mathrm{~mm}$ id, Varian) mounted across a 6 port, 2 position Valco valve set in the "load" position. The adsorbent tube was Peltier-cooled to $15^{\circ} \mathrm{C}$, the target sample volume was $20 \mathrm{ml}$. Oxygen and residual moisture were purged from the adsorbent bed using dry helium before the Valco valve was switched to the "inject" position and the adsorbent tube was heated to $190^{\circ} \mathrm{C}$ for $15 \mathrm{~s}$ in the helium carrier flow. The column (Restek MXT 502.2, $20 \mathrm{~m}$ long, $0.18 \mathrm{~m}$ i.d., $1 \mu \mathrm{m}$ film thickness) was held at $28^{\circ} \mathrm{C}$ for $6 \mathrm{~min}$ then heated to $132^{\circ} \mathrm{C}$ at $6{ }^{\circ} \mathrm{C} \mathrm{min}-1$, and the helium carrier gas pressure was increased to compensate for the increase in gas viscosity during the temperature program. The analytes were directed into the ECD (Agilent micro volume model no. G2397-60510) running at $250{ }^{\circ} \mathrm{C}$. Target peaks in chromatograms from the inter-calibration standard were calibrated using the response curve for each compound generated from the calibration chromatograms using the Cambridge working standard. These enable the tracking of small changes in detector non-linearity, which are taken into account in the work-up of the data. For $\mathrm{CHBr}_{3}$ and $\mathrm{CH}_{2} \mathrm{Br}_{2}$, the response is reasonably linear (Gostlow et al., 2010). With the current chromatographic set-up, $\mathrm{CH}_{2} \mathrm{Br}_{2}$ and $\mathrm{CHBrCl}_{2}$ co-elute (O'Brien et al., 2009). For this comparison, the SX$3570 \mathrm{CHBrCl}_{2}$ mixing ratio assigned by NOAA was subtracted from the combined value for the unresolved $\mathrm{CH}_{2} \mathrm{Br}_{2}$ and $\mathrm{CHBrCl}_{2}$ peaks determined by Cambridge, in order to allow as close a comparison of the $\mathrm{CH}_{2} \mathrm{Br}_{2}$ mixing ratios as possible. The uncertainty in the NOAA assigned $\mathrm{CHBrCl}_{2}$ mixing ratio (estimated to be $10 \%, 1 \sigma$ ) is incorporated into the uncertainty in the $\mathrm{CH}_{2} \mathrm{Br}_{2}$ mixing ratio reported by the University of Cambridge (see below).

Measurement precision is calculated for each target compound as the standard deviation of the 8 replicates of the standard SX-3570. The uncertainty in the reported dry air mole fraction for each target compound is calculated directly from the estimated scale uncertainties from NOAA-ESRL: $10 \%$ for $\mathrm{CHBr}_{3}$ and $20 \%$ for $\mathrm{CH}_{3} \mathrm{I}$ and $\mathrm{CH}_{2} \mathrm{Br}_{2}(2 \sigma)$.

\subsubsection{University of East Anglia}

All samples were dried on-line prior to analysis using a glass tube filled with $\mathrm{Mg}(\mathrm{ClO} 4)_{2}$. The regulator and inlet system were flushed three times with standard gas prior to each analysis, using a volume of $\sim 80 \mathrm{ml}$ of gas. Subsequently the condensable trace gases were pre-concentrated from $\sim 250 \mathrm{ml}$ of air at $-78^{\circ} \mathrm{C}$ in a $1 / 16^{\prime \prime}$ sample loop filled with an adsorbent (Hayesep D, 80/100 mesh) which was heated to 100 ${ }^{\circ} \mathrm{C}$ immediately after injection. Separation was carried out using an Agilent 6890 gas chromatograph with an Agilent GS-GasPro column (length $30 \mathrm{~m}$, ID $0.32 \mathrm{~mm}$ ) coupled to a high sensitivity tri-sector (EBE) mass spectrometer from Micromass/Waters Corporation (AutoSpec Premier). The MS was operated in EI-SIR (Electron Impact-Selected Ion Recording) mode, at a mass resolution of 1000 . The column temperature was held at $-10^{\circ} \mathrm{C}$ for two minutes and then ramped from $-10^{\circ} \mathrm{C}$ to $200^{\circ} \mathrm{C}$ at $10^{\circ} \mathrm{C} \mathrm{min}^{-1}$ (Laube et al., 2010). $\mathrm{CH}_{3} \mathrm{I}$ was quantified using the $\mathrm{I}^{+}$ion $(\mathrm{m} / z, 126.91)$ whilst $\mathrm{CH}_{2} \mathrm{Br}_{2}$ was quantified via $\mathrm{CH}_{2}\left({ }^{79} \mathrm{Br}\right)^{+}(\mathrm{m} / z$ 92.93) and $\mathrm{CHBr}_{3}$ on $\mathrm{CH}\left({ }^{79} \mathrm{Br}\right)\left({ }^{81} \mathrm{Br}\right)^{+}(\mathrm{m} / z, 172.84)$.

The inter-calibration standard SX-3570 was measured four times against an internal standard (Aculife-treated aluminium cylinder) filled with remote tropospheric air from 
Niwot Ridge near Boulder, USA. The latter was brought in line with NOAA calibration scales (the 2003 scale for $\mathrm{CHBr}_{3}$ and 2004 scale for $\mathrm{CH}_{3} \mathrm{I}$ and $\left.\mathrm{CH}_{2} \mathrm{Br}_{2}\right)$ by measuring it against two tertiary standards (351 electropolished stainless steel canisters from Essex Cryogenics, also from Niwot Ridge, measurements in May 2010, four repeats each) which were obtained from, and calibrated by, NOAA-ESRL in 2009. Throughout these analyses, blank signals were much smaller than the reported measurement precision, and were thus not considered. Analysis of the SX-3570 standard demonstrates that this system produces a linear response for $\mathrm{CH}_{3} \mathrm{I}, \mathrm{CH}_{2} \mathrm{Br}_{2}$ and $\mathrm{CHBr}_{3}$ up to $2-5 \mathrm{ppt}$.

\subsubsection{Plymouth Marine Laboratory}

VSLH in seawater were analysed based upon the methods outlined by Hughes et al. (2008). Calibration and quantification of VSLH were performed using laboratory-prepared liquid standards, by dilution of the pure compounds into HPLCgrade methanol. The primary standards were prepared gravimetrically, while the secondary and working standards were prepared by serial dilution. Microlitre volumes of the working standards were injected into seawater, and these standards were used to achieve multi-point calibrations, taking into account individual purge efficiencies of the VSLH.

Halocarbons were extracted from the water phase by purging with ultra high purity (BIP) nitrogen at $90 \mathrm{ml} \mathrm{min}^{-1}$ for 10 minutes. Aerosols and moisture were removed from the purge gas stream using glass wool contained within a section of glass tubing, and a counterflow Nafion drier using oxygenfree nitrogen at $180 \mathrm{ml} \mathrm{min}^{-1}$. Halocarbons were trapped on triple-bed stainless steel solid sorbent tubes (Markes International Ltd.) containing Tenax, Carbograph and Carboxen. During sample collection, the tubes were held in a Peltier temperature-controlled block held at $1-2{ }^{\circ} \mathrm{C}$. For the purposes of the inter-calibration, sample volumes of $0.5,1.0$, 1.5 and 2.01 of the NOAA SX-3570 standard were passed through a Nafion drier (Permapure ${ }^{\mathrm{TM}}$ ) before being trapped on Markes sorbent tubes as described above. Molar concentrations were derived for components of SX-3570 based upon purge-efficiency-corrected aqueous phase calibrations, and converted to ppt in order to allow comparison with the mixing ratios reported by other institutions. The instrument response was linear for 0.5-2.01 gas for all three compounds $\left(R^{2}>0.99\right)$, and no blank corrections were applied.

Seawater calibration standards and SX-3570 samples were analysed using an Agilent GC-MS (5973N), coupled to a Markes Unity thermal desorption (TD) platform. The GC is fitted with a $60 \mathrm{~m}$ DB-VRX capillary column $(0.32 \mu \mathrm{m}$ film thickness, J \& W Ltd. $)$, and the MS was operated in electron ionization (EI)/single ion mode (SIM) throughout the analyses. $\mathrm{CH}_{3} \mathrm{I}$ was quantified using the $\mathrm{CH}_{3} \mathrm{I}^{+}$ion $\left(\mathrm{m} / z\right.$ 142), $\mathrm{CH}_{2} \mathrm{Br}_{2}$ via $\mathrm{CH}_{2}\left({ }^{79} \mathrm{Br}\right)\left({ }^{81} \mathrm{Br}\right)^{+}$ $(m / z, 174)$ and $\mathrm{CHBr}_{3}$ on $\mathrm{CH}\left({ }^{79} \mathrm{Br}\right)\left({ }^{81} \mathrm{Br}\right)^{+}(m / z$ 173). The instrument response was linear for $\mathrm{CH}_{3} \mathrm{I}\left(0-4 \mathrm{pmoll}^{-1}\right.$,
$\left.R^{2}>0.98\right), \mathrm{CH}_{2} \mathrm{Br}_{2}\left(0-14\right.$ pmol $\left.^{-1}, R^{2}>0.99\right)$ and $\mathrm{CHBr}_{3}$ (0-15 pmol $\left.1^{-1} R^{2}>0.99\right)$. Within Unity, the sample tube was heated to $200^{\circ} \mathrm{C}$, and the sample refocused onto a cold trap held at $-10^{\circ} \mathrm{C}$. Following this, the cold trap was rapidly heated at $100^{\circ} \mathrm{C} \mathrm{s}^{-1}$ to $290^{\circ} \mathrm{C}$, introducing the sample to the GC column with a helium carrier gas flow rate of $2 \mathrm{ml} \mathrm{min}^{-1}$. The GC oven temperature was held at $40^{\circ} \mathrm{C}$ for $5 \mathrm{~min}$, increased at $20^{\circ} \mathrm{C} \mathrm{min}^{-1}$ to $200^{\circ} \mathrm{C}$ and held for $2 \mathrm{~min}$, before increasing at $20^{\circ} \mathrm{C} \mathrm{min}^{-1}$ to $240{ }^{\circ} \mathrm{C}$, and held for $4 \mathrm{~min}$. GC-MS sensitivity drift was monitored and corrected for by injecting constant volumes of deuterated halocarbons $\left(\mathrm{CD}_{3} \mathrm{I},\left(\mathrm{CD}_{3}\right)_{2} \mathrm{CDI}\right)$ into each sample (prepared as for calibration standards from pure compounds) (Hughes et al., 2006, 2008). Total measurement uncertainties for each compound were estimated from the combined uncertainties (root sum of squares) of the following; volumes of liquid halocarbon standard additions at each stage during serial dilution, volumes of liquid standard additions to seawater samples, purge flow rate, and the uncertainty in the calibration linear regression. Precision was estimated as the standard deviation of repeat measurements performed during the calibration.

\subsubsection{University of York}

Analyses were carried out using an Agilent Technologies 6850 gas chromatograph coupled to a 5975C mass selective detector with an electron ionization source and operating in single ion mode (SIM). All samples were passed through a Nafion drier (Permapure ${ }^{\mathrm{TM}}$ ) prior to preconcentration of volatile components onto a Peltier cooled $\left(-20^{\circ} \mathrm{C}\right)$ adsorbent trap (UNITY2 ${ }^{\mathrm{TM}} \&$ CIA8, Markes International Ltd.). Sample lines were flushed with $100 \mathrm{ml}$ sample gas prior to trapping. Analytes were thermally desorbed by heating the trap to $300{ }^{\circ} \mathrm{C}$, and separated using an HP5-MS column (25 m, $0.25 \mathrm{~mm} \mathrm{ID,} 0.25 \mathrm{mi}-$ cron film, Agilent $\mathrm{J} \& \mathrm{~W}) . \mathrm{CH}_{3} \mathrm{I}$ was quantified using the $\mathrm{CH}_{3} \mathrm{I}^{+}$ion $(\mathrm{m} / z, 142)$ with $\mathrm{I}^{+}(\mathrm{m} / \mathrm{z}, 127)$ as a qualifier, whilst $\mathrm{CH}_{2} \mathrm{Br}_{2}$ was quantified via $\mathrm{CH}_{2}\left({ }^{79} \mathrm{Br}\right)\left({ }^{81} \mathrm{Br}\right)^{+}$ $\left(m / z\right.$ 174) with $\mathrm{CH}_{2}\left({ }^{79} \mathrm{Br}\right)\left({ }^{79} \mathrm{Br}\right)^{+}(\mathrm{m} / z$ 172) as a qualifier ion, and finally $\mathrm{CHBr}_{3}$ on $\mathrm{CH}\left({ }^{79} \mathrm{Br}\right)\left({ }^{81} \mathrm{Br}\right)^{+}(\mathrm{m} / z$ 173) with $\mathrm{CH}\left({ }^{79} \mathrm{Br}\right)\left({ }^{79} \mathrm{Br}\right)^{+}(\mathrm{m} / \mathrm{z}, 171)$ as a qualifier ion.

Sample volumes of 1.0, 1.5 and 2.01 of the NOAA intercalibration standard were analysed to produce a linear response curve. No VSLH signals were detected in nitrogenonly blank samples, and as such blank corrections were deemed unnecessary. Calibration of VSLH was achieved using a permeation oven based dynamic dilution technique based on Wevill and Carpenter (2004). Individual permeation tubes (Eco Scientific) containing pure VSLH liquids are contained in one of two temperature controlled ovens (thermostatic at 40 and $70^{\circ} \mathrm{C}$ ) and each tube permeates a single gaseous VSLH at a steady rate. Zero grade nitrogen flows through the system at $100 \mathrm{ml} \mathrm{min}^{-1}$ and dilutes the VSLH permeation gas to $\sim$ ppm (parts per million) levels. Loop injections of $25 \mu \mathrm{L}$ volumes of this gas are diverted to the 
instrument to achieve a multi-point calibration at ppt levels, and these calibrations were used to determine mixing ratios of VSLH in the inter-calibration standard SX-3570. The permeation tubes are weighed periodically (using a KERN 770 mass balance, accurate to $0.01 \mathrm{mg}$ ), typically every 6 weeks over a period of $\sim 1$ year, to calculate the permeation rates. The estimated uncertainty of this calibration technique is $\pm 12 \%$, calculated from the combined uncertainties due to the variance of the permeation tube weighings, the calibration linear regression, and uncertainties in loop volumes and flow rates.

\section{Results}

Butler et al. (2010) recommend that in the first instance, inter-laboratory comparisons should focus upon the species $\mathrm{CH}_{3} \mathrm{I}, \mathrm{CH}_{2} \mathrm{Br}_{2}$ and $\mathrm{CHBr}_{3}$, since these are the most widely reported of the short-lived halocarbons in both the atmosphere and ocean (e.g. Quack and Wallace, 2003; Chuck et al., 2005; Yokouchi et al., 2005; Butler et al., 2007; Quack et al., 2007; Carpenter et al., 2009) and have also been the focus of the majority of tropospheric VSLH modelling studies to date (e.g. Warwick et al., 2006; Palmer and Reason, 2009). In addition, NOAA-ESRL have characterised the stability of these species in compressed gas cylinders over prolonged periods (Butler et al., 2007, Supplement), whilst to date the stability of shorter-lived iodine-containing VSLH such as $\mathrm{CH}_{2} \mathrm{I}_{2}$ and $\mathrm{CH}_{2} \mathrm{ICl}$ has not been well studied. Thus, although these iodine containing dihalomethanes arguably play an equally important role in tropospheric halogen photochemistry, their analysis has been excluded from the following discussion.

Each laboratory that participated in the inter-comparison used their existing measurement and calibration technique (detailed above) to determine the mixing ratios of $\mathrm{CH}_{3} \mathrm{I}$, $\mathrm{CH}_{2} \mathrm{Br}_{2}$ and $\mathrm{CHBr}_{3}$ within the NOAA standard SX-3570. The results of these analyses are summarised in Table 1 and Fig. 1. The comparisons were carried out blind (i.e. the halocarbon mixing ratios in the NOAA SX-3570 gas standard were unknown), with the exception of the University of York calibration, where, as coordinators of the comparison, the scientists carrying out the analyses had prior knowledge of the NOAA-assigned mixing ratios.

The mixing ratios determined by each laboratory are reported in Table 1, together with the associated $2 \sigma$ analytical precision and estimated $2 \sigma$ overall measurement uncertainty. The total uncertainties are a combination of bias (e.g. potential wall losses/gains, flow errors, gravimetric errors) and precision errors. The precision error is presumed to behave randomly, with a zero mean. Both the bias and precision are presumed to represent stationary statistical properties of a Gaussian distributed data set. Assuming that the errors are un-correlated, the total uncertainty may be estimated from the sum of squares of all the bias and precision errors (Moffat, 1988).
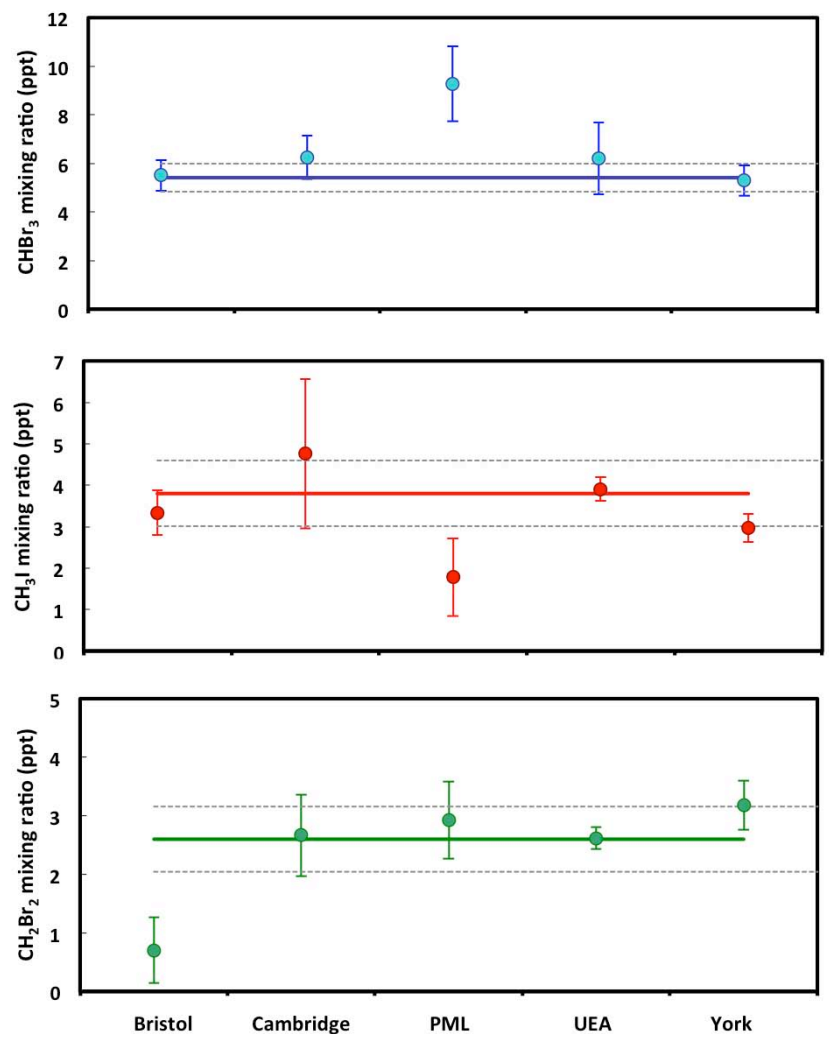

Fig. 1. $\mathrm{CHBr}_{3}, \mathrm{CH}_{3} \mathrm{I}$ and $\mathrm{CH}_{2} \mathrm{Br}_{2}$ mixing ratios determined by each research group, with estimated $2 \sigma$ measurement uncertainties. The solid line in each plot corresponds to the NOAA-assigned mixing ratio, and the grey dotted lines indicate the estimated $2 \sigma$ uncertainty in the NOAA values.

It is important to stress that several different calibration scales exist for these gases, and there is no formal consensus as to which is the most accurate. As such, the data points with greater deviation from the NOAA-assigned values should not necessarily be considered "incorrect". The purpose of this study is simply to identify systematic offsets between observations from the different institutions, in order to improve comparability between datasets.

The two institutions that already use the NOAA scale for VSLH calibration (University of Cambridge and University of East Anglia) reported mixing ratios which were most consistently in good agreement with the NOAA-assigned values across all compounds (ranging from within $\sim 0.5-25 \%$ depending upon the species). Although both institutions report $\mathrm{CHBr}_{3}$ mixing ratios $\sim 0.8 \mathrm{ppt}$ larger than the NOAAassigned value, and in excellent agreement with each other (within 1\%), all three values are consistent within the uncertainties of the measurements. The UoC, UEA and SX3570 VSLH gas standards were all prepared and analysed by the NOAA laboratory at around the same time (AugustSeptember 2009).

Despite not currently using the NOAA scale for VSLH calibrations, both the Universities of York and Bristol report 
$\mathrm{CHBr}_{3}$ mixing ratios in excellent agreement with the NOAAassigned value (within $2 \%$ ), and $\mathrm{CH}_{3} \mathrm{I}$ mixing ratios equivalent to the NOAA value, within the measurement uncertainties. UoY calibrated $\mathrm{CH}_{2} \mathrm{Br}_{2}$ in $\mathrm{SX}-3570$ slightly higher than NOAA (although in reasonable agreement taking into account the measurement uncertainties), whilst UoB calibrated $\mathrm{CH}_{2} \mathrm{Br}_{2}$ some $\sim 2-3$ times lower than NOAA.

The group based at Plymouth Marine Laboratory primarily analyse VSLH concentrations in seawater, and do not routinely make atmospheric measurements of these gases. As such, their normal sampling methods had to be modified in order to carry out the gas-phase calibrations, and this should be taken into consideration when interpreting their reported values. The PML-assigned $\mathrm{CH}_{2} \mathrm{Br}_{2}$ mixing ratio was nevertheless in good agreement with the NOAA analyses (within $\sim 12 \%$, and equivalent within measurement uncertainties). However, the $\mathrm{CH}_{3} \mathrm{I}$ and $\mathrm{CHBr}_{3}$ mixing ratios reported by PML differed from the NOAA-assigned values by $\sim 25 \%$ and $\sim 45 \%$, respectively, which is outside of measurement uncertainties.

The apparent discrepancies between aqueous and gas phase $\mathrm{CH}_{3} \mathrm{I}$ and $\mathrm{CHBr}_{3}$ calibrations result in PML underestimating $\mathrm{CH}_{3} \mathrm{I}$ and over-estimating $\mathrm{CHBr}_{3}$ mixing ratios in the SX-3570 gas standard. Over-estimation of $\mathrm{CHBr}_{3}$ might potentially be explained by incomplete sparging of $\mathrm{CHBr}_{3}$ from seawater standards (although purge efficiencies have previously been measured, and are taken into account in the PML calibrations, see Sect. 2.2.4), whilst under-estimation of $\mathrm{CH}_{3} \mathrm{I}$ could result from breakthrough when sampling SX3570 gas onto the sorbent tubes. $\mathrm{CH}_{3} \mathrm{I}$ is the most volatile of the three VSLH studied here, and thus is most susceptible to breakthrough.

The mean and median of all the independently derived $\mathrm{CH}_{3} \mathrm{I}, \mathrm{CH}_{2} \mathrm{Br}_{2}$ and $\mathrm{CHBr}_{3}$ mixing ratios are in reasonably good agreement (within $2-15 \%$ for median, $7-21 \%$ for mean) with the NOAA-assigned values. The largest discrepancy is between the average independently derived $\mathrm{CHBr}_{3}$ mixing ratio and the figure reported by NOAA, however this is skewed by the high PML mixing ratio value; removing this value gives a mean (and median) of $\sim 5.8$ ppt $\mathrm{CHBr}_{3}$, bringing the agreement to within $8 \%$.

The largest deviation between the reported mixing ratios was observed in the analysis of $\mathrm{CH}_{2} \mathrm{Br}_{2}(41 \%)$, whilst the closest agreement was between $\mathrm{CHBr}_{3}$ measurements $(25 \%$ deviation). Excluding the PML values, the deviation between the $\mathrm{CHBr}_{3}$ mixing ratios was reduced to $\sim 8 \%$, and the spread in reported $\mathrm{CH}_{3} \mathrm{I}$ values was also reduced, from $33 \%$ to $\sim 20 \%$.

\section{Conclusions and future work}

The results from the first UK national comparison for shortlived halocarbon calibrations provide a significant step forward to achieving the long-term goal of an internationally recognised calibration scale. This in turn will facilitate use of a coherent central database, containing a vast quantity of globally distributed VSLH measurements, and hence potentially lead to improved global source term parameterisations for these gases.

Since the ultimate long-term aim of these comparisons is to reduce the uncertainty in global emission estimates, we consider the spread in calibration scales for $\mathrm{CHBr}_{3}, \mathrm{CH}_{2} \mathrm{Br}_{2}$ and $\mathrm{CH}_{3} \mathrm{I}$ found in this study compared with the current uncertainty in their global budgets. Current global oceanic $\mathrm{CHBr}_{3}$ flux estimates range from $240-1760 \mathrm{Gg} \mathrm{Bryr}^{-1}$ (Quack and Wallace, 2003; Warwick et al., 2006; Butler et al., 2007), equivalent to $\sim 1000 \mathrm{Gg} \mathrm{Bryr}^{-1} \pm 75 \%$, an uncertainty considerably larger than the variation in the $\mathrm{CHBr}_{3}$ calibration scales identified in this study. Likewise, the $\mathrm{CH}_{3} \mathrm{I}$ global budget is estimated as $\sim 330 \mathrm{Gg} \mathrm{I} \mathrm{yr}^{-1} \pm 65 \%$ (ranging from 114-546 $\mathrm{Gg} \mathrm{Iyr}^{-1}$, Moore and Groszko, 1999; Bell et al., 2002; Butler et al., 2007; Jones et al., 2010), which equates to an uncertainty substantially greater than the spread in $\mathrm{CH}_{3} \mathrm{I}$ calibrations. Despite exhibiting the most variability between calibration scales, the $\sim 66 \%$ uncertainty in the estimated global $\mathrm{CH}_{2} \mathrm{Br}_{2}$ source term $\left(\sim 169 \mathrm{Gg} \mathrm{Br} \mathrm{yr}^{-1} \pm 66 \%\right.$; Butler et al., 2007; Liang et al., 2010) still outweighs the discrepancies which might result from use of the different calibration scales reported here.

The results from this study suggest that gas phase $\mathrm{CHBr}_{3}$ calibrations made by UK atmospheric research institutes are in good agreement, however this comparison also indicates that cross-calibrating between gaseous and dissolved VSLH is not straightforward. Compared to $\mathrm{CHBr}_{3}$, there are larger discrepancies between gas phase $\mathrm{CH}_{3} \mathrm{I}$ calibration scales, while $\mathrm{CH}_{2} \mathrm{Br}_{2}$ calibrations proved the least consistent of the VSLH analysed during this comparison.

Given the apparent discrepancies between aqueous and gas phase calibrations for $\mathrm{CH}_{3} \mathrm{I}$ and $\mathrm{CHBr}_{3}$ observed in this study, we suggest that future comparisons between aqueous and gas phase instruments should (a) use a range of primary liquid standards when preparing working standards to assess the potential variability of using liquid compared to gaseous standards and (b) evaluate any systematic differences between gas phase and aqueous phase analyses of different methods. The latter could be achieved by using a common gaseous standard for calibration of instruments, in-conjunction with analysis of a common aqueous sample (analyses of aqueous samples would have to be carried out near simultaneously to avoid any degradation). Groups using liquid standards should be able to report the comparability of these from one campaign to the next, i.e. be able to compare to a primary standard. Likewise, groups using NOAA gaseous standards for calibration should routinely return cylinders for reanalysis.

On a national scale, the next desirable stage in this process would be for each institution to submit their $\mathrm{CH}_{3} \mathrm{I}$, $\mathrm{CH}_{2} \mathrm{Br}_{2}$ and $\mathrm{CHBr}_{3}$ observations to the HalOcAt database, calibrated both according to their existing calibration scale, 
and adjusted for the common, NOAA, scale. As well as achieving comparability on a national level, this will also enable measurements from the UK research groups that took part in this inter-calibration to be interpreted alongside the large database of $\mathrm{CH}_{3} \mathrm{I}, \mathrm{CH}_{2} \mathrm{Br}_{2}$ and $\mathrm{CHBr}_{3}$ observations already published using the NOAA scale (Butler et al., 2007). A summary of relevant VSLH publications from the institutions that took part in this inter-calibration is provided as a Supplement.

In order to achieve a reliable inter-comparison of those VSLH that are potentially less stable in canisters and have even shorter lifetimes than $\mathrm{CH}_{3} \mathrm{I}, \mathrm{CH}_{2} \mathrm{Br}_{2}$ and $\mathrm{CHBr}_{3}$ (such as $\mathrm{CH}_{2} \mathrm{I}_{2}$ and $\mathrm{CH}_{2} \mathrm{ICl}$ ), the general consensus is that colocating all instruments to perform simultaneous measurements, for example via an in-situ field-based comparison, would be the best approach. As some of the polyhalogenated VSLH are rapidly photolysed by sunlight and can also be less volatile and susceptible to wall losses, the sampling technique used when quantifying these species is potentially as important as the calibration method itself. Simultaneous analyses of VSLH in ambient air would allow for a more thorough inter-comparison, testing the whole measurement system in addition to the calibration scale. Furthermore, this approach would also provide a mechanism through which inter-laboratory comparisons could be extended to include measurements of VSLH in seawater. Comparisons of dissolved VSLH may prove more challenging than gas phase inter-calibrations (since sparging efficiencies add an additional level of complexity, and degradation within the water may make sequential sampling of one standard over a period of a few months impractical), however these studies are necessary, since seawater measurements form a critical component of the global VSLH budget.

In the long-term, this national inter-laboratory comparison of VSLH calibrations should be repeated at frequent intervals (ideally on an annual basis), in order to maintain confidence in the level of comparability, and should ideally also be extended to include other international institutions. In addition, explanations for the differences in the calibration scales highlighted here should be explored, and the VSLH standard SX-3570 should be returned to the NOAA-ESRL for reanalysis, in order to assess any drift in mixing ratios which may have occurred since the initial analyses. Funding for this type of activity is generally not readily available, yet establishing a robust, long-term inter-laboratory comparison protocol for VSLH calibration is crucial to creating a coherent, integrated global database for these gases, and will underpin any future studies aiming to use such a database to achieve improved estimates for global VSLH source terms.

\section{Supplementary material related to this article is available online at: http://www.atmos-meas-tech.net/4/865/2011/ amt-4-865-2011-supplement.pdf.}

Acknowledgements. For funding the VSLH workshop, we are grateful to the SOLAS International Project Office (IPO); the Natural Environment Research Council (NERC) through UK-SOLAS Knowledge Transfer funds; and the European Science Foundation (ESF) through COST (Cooperation in the field of Scientific and Technical Research) Action 735 funds. The UK inter-calibrations were supported by the NERC QUEST programme (NE/C001672/1, subcontract no. RG41718). UEA acknowledge NERC for the Research Fellowship NE/F015585/1. UoB thank the School of Physics, National University of Ireland, Galway, for making the research facilities at Mace Head available. The operation of the halocarbon measurements at Mace Head was funded by the Department of the Energy and Climate Change (DECC, UK) contract GA01103 to the University of Bristol. The University of Cambridge work is supported by NERC on project NE/F020341/1 and a Research Fellowship (NE/GO/4655/1). The authors acknowledge Steve Montzka and Carolina Siso (NOAA-ESRL) for their involvement in the analysis of SX-3570 and the development of the NOAA scales.

Edited by: J.-P. Pommereau

\section{References}

Archer, S. D., Goldson, L. E., Liddicoat, M. I., Cummings, D. G., and Nightingale, P. D.: Marked seasonality in the concentrations and sea-to-air flux of volatile iodocarbon compounds in the western English Channel, J. Geophys. Res., 112, C08009, doi:10.1029/2006JC003963, 2007.

Bell, N., Hsu, L., Jacob, D. J., Schultz, M. G., Blake, D. R., Butler, J. H., King, D. B., Lobert, J. M., and Maier-Reimer, E.: Methyl iodide: Atmospheric budget and use as a tracer of marine convection in global models, J. Geophys. Res., 107(D17), 4340, doi:10.1029/2001JD001151, 2002.

Bloss, W. J., Evans, M. J., Lee, J. D., Sommariva, R., Heard. D. E., and Pilling, M. J.: Impact of halogen monoxide chemistry upon boundary layer $\mathrm{OH}$ and $\mathrm{HO}_{2}$ concentrations at a coastal site, Geophys. Res. Lett., 32(6), L06814, doi:10.1029/2004GL022084, 2005.

Butler, J. H., King, D. B., Lobert, J. M., Montzka, S. A., YvonLewis, S. A., Hall, B. D., Warwick, N. J., Mondeel, D. J., Aydin, M., and Elkins, J. W.: Oceanic distributions and emissions of short-lived halocarbons, Global Biogeochem. Cy., 21, GB1023, doi:10.1029/2006GB002732, 2007.

Butler, J. H., Bell, T. G., Hall, B. D., Quack, B., Carpenter, L. J., and Williams, J.: Technical Note: Ensuring consistent, global measurements of very short-lived halocarbon gases in the ocean and atmosphere, Atmos. Chem. Phys., 10, 327-330, doi:10.5194/acp-10-327-2010, 2010.

Carpenter, L. J., Liss, P. S., and Penkett, S. A.: Marine organohalogens in the atmosphere over the Atlantic and Southern Oceans, J. Geophys. Res.-Atmos., 108(D9), 4256, doi:10.1029/2002JD002769, 2003.

Carpenter, L. J., Wevill, D. J., Hopkins, J. R., Dunk, R. M., Jones, C. E., Hornsby, K. E., and McQuaid, J. B.: Bromoform in tropical Atlantic air from 25 degrees N to 25 degrees S, Geophys. Res. Lett., 34, 11, doi:10.1029/2007GL029893, 2007. 
Carpenter, L. J., Jones, C. E., Dunk, R. M., Hornsby, K. E., and Woeltjen, J.: Air-sea fluxes of biogenic bromine from the tropical and North Atlantic Ocean, Atmos. Chem. Phys., 9, 1805-1816, doi:10.5194/acp-9-1805-2009, 2009.

Chuck, A. L., Turner, S. M., and Liss, P. S.: Oceanic distributions and air-sea fluxes of biogenic halocarbons in the open ocean, J. Geophys. Res., 110, C10022, doi:10.1029/2004JC002741, 2005.

Finlayson-Pitts, B. J. and Pitts, J. N.: Chemistry of the Upper and Lower Atmosphere - Theory, Experiments and Applications, Academic Press, San Diego, CA, USA and London, UK, 2000.

Garcia, R. R. and Solomon, S.: A new numerical model of the middle atmosphere 2. Ozone and related species, J. Geophys. Res.Atmos., 99(D6), 12937-12951, 1994.

Gostlow, B., Robinson, A. D., Harris, N. R. P., O’Brien, L. M., Oram, D. E., Mills, G. P., Newton, H. M., Yong, S. E., and A Pyle, J.: $\mu$ Dirac: an autonomous instrument for halocarbon measurements, Atmos. Meas. Tech., 3, 507-521, doi:10.5194/amt-3507-2010, 2010.

Hughes, C., Malin, G., Nightingale, P. D., and Liss, P. S.: The effect of light stress on the release of volatile iodocarbons by three species of marine microalgae, Limnol. Oceanogr., 51(6), 28492854, 2006.

Hughes, C., Chuck, A. L., Rossetti, H., Mann, P. J., Turner, S. M., Clarke, A., Chance, R., and Liss, P. S: Seasonal cycle of seawater bromoform and dibromomethane concentrations in a coastal bay on the western Antactic Peninsula, Global Biogeochem. Cy., 23, GB2024, doi:10.1029/2008GB003268, 2008.

Jones, C. E., Hornsby, K. E., Sommariva, R., Dunk, R. M., von Glasow, R., McFiggans, G., and Carpenter, L. J.: Quantifying the contribution of marine organic gases to atmospheric iodine, Geophys. Res. Lett., 37, L18804, doi:10.1029/2010GL043990, 2010.

Kurihara, M. K., Kimurab, M., Iwamotoc, Y., Naritac, Y., Ookid, A., Eume, Y.-J., Tsudac, A., Suzukie, K., Tanib, Y., Yokouchi, Y., Uematsuc, M., and Hashimotoa, S.: Distributions of shortlived iodocarbons and biogenic trace gases in the open ocean and atmosphere in the western North Pacific, Mar. Chem., 118, 156170, 2010.

Laube, J. C., Engel, A., Bönisch, H., Möbius, T., Worton, D. R., Sturges, W. T., Grunow, K., and Schmidt, U.: Contribution of very short-lived organic substances to stratospheric chlorine and bromine in the tropics - a case study, Atmos. Chem. Phys., 8, 7325-7334, doi:10.5194/acp-8-7325-2008, 2008.

Laube, J. C., Martinerie, P., Witrant, E., Blunier, T., Schwander, J., Brenninkmeijer, C. A. M., Schuck, T. J., Bolder, M., Röckmann, T., van der Veen, C., Bönisch, H., Engel, A., Mills, G. P., Newland, M. J., Oram, D. E., Reeves, C. E., and Sturges, W. T.: Accelerating growth of HFC-227ea (1,1,1,2,3,3,3-heptafluoropropane) in the atmosphere, Atmos. Chem. Phys., 10, 5903-5910, doi:10.5194/acp-10-5903-2010, 2010.

Law, K. S. and Sturges, W. T.: Halogenated very short-lived substances, Chapter 2 in: Scientific Assessment of Ozone Depletion: 2006, Global Ozone Research and Monitoring Project - Report No. 50, World Meteorological Organization, Geneva, Switzerland, 572 pp., 2007.

Liang, Q., Stolarski, R. S., Kawa, S. R., Nielsen, J. E., Douglass, A. R., Rodriguez, J. M., Blake, D. R., Atlas, E. L., and Ott, L. E.: Finding the missing stratospheric $\mathrm{Br}_{\mathrm{y}}$ : a global modeling study of $\mathrm{CHBr}_{3}$ and $\mathrm{CH}_{2} \mathrm{Br}_{2}$, Atmos. Chem. Phys., 10, 2269-2286, doi:10.5194/acp-10-2269-2010, 2010.

Mahajan, A. S., Plane, J. M. C., Oetjen, H., Mendes, L., Saunders, R. W., Saiz-Lopez, A., Jones, C. E., Carpenter, L. J., and McFiggans, G. B.: Measurement and modelling of tropospheric reactive halogen species over the tropical Atlantic Ocean, Atmos. Chem. Phys., 10, 4611-4624, doi:10.5194/acp-10-46112010, 2010.

Miller, B. R., Weiss, R. F., Salameh, P. K., Tanhua, T., Greally, B. R., Mühle, J., and Simmonds, P. G.: Medusa: A Sample Preconcentration and GC/MS Detector System for in Situ Measurements of Atmospheric Trace Halocarbons, Hydrocarbons, and Sulfur Compounds, Anal. Chem., 80, 1536-1545, doi:10.1021/ac702084k, 2008.

Moffat, R. J.: Describing the Uncertainties in Experimental Results, Exp. Therm. Fluid Sci., 1, 3-17, 1988.

Montzka, S. A. and Reimann, S.: Ozone depleting substances (ODS's) and related chemicals, Chapter 1 in: Scientific Assessment of Ozone Depletion: 2010, Global Ozone Research and Monitoring Project, Report No. 52, 373 pp., 2011.

Montzka, S. A., Myers, R. C., Butler, J. H., Elkins, J. W., and Cummings, S. O.: Global tropospheric distribution and calibration scale of HCFC-22, Geophys. Res. Lett., 20, 703-706, 1993.

Montzka, S. A., Myers, R. C., Butler, J. H., Elkins, J. W., Lock, L. T., Clarke, A. D., and Goldstein, A. H.: Observations of HFC134a in the remote troposphere, Geophys. Res. Lett., 23, 169$172,1996$.

Moore, R. M. and Groszko, W.: Methyl iodide distribution in the ocean and fluxes to the atmosphere, J. Geophys. Res., 104(C5), 11163-11171, 1999.

O’Brien, L. M., Harris, N. R. P., Robinson, A. D., Gostlow, B., Warwick, N., Yang, X., and Pyle, J. A.: Bromocarbons in the tropical marine boundary layer at the Cape Verde Observatory - measurements and modelling, Atmos. Chem. Phys., 9, 90839099, doi:10.5194/acp-9-9083-2009, 2009.

Palmer, C. J. and Reason, C. J.: Relationships of surface bromoform concentrations with mixed layer depth and salinity in the tropical oceans, Global Biogeochem. Cy., 23, GB2014, doi:10.1029/2008GB003338, 2009.

Quack, B. and Wallace, D. W. R.: Air-sea flux of bromoform: Controls, rates, and implications, Global Biogeochem. Cy., 7(1), 1023, doi:10.1029/2002GB001890, 2003.

Quack, B., Atlas, E., Petrick, G., and Wallace, D. W. R.: Bromoform and dibromomethane above the Mauritanian upwelling: Atmospheric distributions and oceanic emissions, J. Geophys. Res., 112, D09312, doi:10.1029/2006JD007614, 2007.

Read, K. A., Mahajan, A. S., Carpenter, L. J., Evans, M. J., Faria, B. V. E., Heard, D. E., Hopkins, J. R., Lee, J. D., Moller, S. J., Lewis, A. C., Mendes, L., McQuaid, J. B., Oetjen, H., SaizLopez, A., Pilling, M. J., and Plane, J. M. C.: Extensive halogen mediated ozone destruction over the tropical Atlantic Ocean, Nature, 453, 1232-1235, doi:10.1038/nature07035, 2008.

Sturges, W. T., Oram, D. E., Carpenter, L. J., Penkett, S. A., and Engel, A.: Bromoform as a source of stratospheric bromine, Geophys. Res. Lett., 27(14), 2081-2084, 2000.

Varner, R. K., Zhou, Y., Russo, R. S., Wingenter, O. W., Atlas, E., Stroud, C., Mao, H., Talbot, R., and Sive, B. C.: Controls on atmospheric chloroiodomethane $\left(\mathrm{CH}_{2} \mathrm{ClI}\right)$ in marine environments, J. Geophys. Res., 113, D10303, 
doi:10.1029/2007JD008889, 2008.

Vogt, R., Sander, R., von Glasow, R., and Crutzen, P. J.: Iodine chemistry and its role in halogen activation and ozone loss in the marine boundary layer: A model study, J. Atmos. Chem., 32(3), 375-395, 1999.

von Glasow, R., von Kuhlmann, R., Lawrence, M. G., Platt, U., and Crutzen, P. J.: Impact of reactive bromine chemistry in the troposphere, Atmos. Chem. Phys., 4, 2481-2497, doi:10.5194/acp4-2481-2004, 2004.

Warwick, N. J., Pyle, J. A., Carver, G. D., Yang, X., Savage, N. H., O'Connor, F. M., and Cox, R. A.: Global modeling of biogenic bromocarbons, J. Geophys. Res., 111, D24305, doi:10.1029/2006JD007264, 2006.

Wevill, D. J. and Carpenter, L. J.: Automated measurement and calibration of reactive volatile halogenated organic compounds in the atmosphere, Analyst, 129(7), 634-638, doi:10.1039/b403550j, 2004.
Whalley, L. K., Furneaux, K. L., Goddard, A., Lee, J. D., Mahajan, A., Oetjen, H., Read, K. A., Kaaden, N., Carpenter, L. J., Lewis, A. C., Plane, J. M. C., Saltzman, E. S., Wiedensohler, A., and Heard, D. E.: The chemistry of $\mathrm{OH}$ and $\mathrm{HO}_{2}$ radicals in the boundary layer over the tropical Atlantic Ocean, Atmos. Chem. Phys., 10, 1555-1576, doi:10.5194/acp-10-1555-2010, 2010.

Yang, X., Cox, R. A., Warwick, N. J., Pyle, J. A., Carver, G. D., O'Connor, F. M., and Savage, N. H.: Tropospheric bromine chemistry and its impacts on ozone: A model study, J. Geophys. Res.-Atmos., 110, D23311, doi:10.1029/2005JD006244, 2005.

Yokouchi, Y., Hasebe, F., Fujiwara, M., Takashima, H., Shiotani, M., Nishi, N., Kanaya, Y., Hashimoto, S., Fraser, P., ToomSauntry, D., Mukai, H., and Nojiri, Y.: Correlations and emission ratios among bromoform, dibromochloromethane, and dibromomethane in the atmosphere, J. Geophys. Res., 110, D23309, doi:10.1029/2005JD006303, 2005. 